УДК 336.14

Матвійчук В. І., к. е. Н., доцент кафедри фрінансів та банківської справи Донецького національного університету імені Василя Стуса

Грабчак К. М., магістрант Донецького національного університету імені Василя Стуса

\title{
ДОХОДИ МІСЦЕВОГО БЮДЖЕТУ: ПРОБЛЕМИ ФОРМУВАННЯ ТА ОСОБЛИВОСТІ ВИКОРИСТАННЯ
}

Охарактеризовано сучасні тенденції у формуванні та використанні фінансових ресурсів місцевого бюджету. Досліджено динаміку обсягу доходів місцевого бюджету Бершадського району Вінницької області та їх складових за 2013-2017 роки. Проаналізовано структуру доходів місцевого бюджету Бершадського району. Виявлено, що при зростанні обсягу доходів їх структура зберігається практично незмінною протягом останніх п'яти років та характеризується збереженням значної питомої ваги міжбюджетних трансфертів. Докладно вивчено зміни в обсягах та структурі кожної складової дохідної частини місцевого бюджету. Розглянуто структуру використання коштів місцевого бюджету. Розроблено економіко-математичну модель формування дохідної частини місцевого бюджету Бершадського району з урахуванням дії наступних факторів: кількість зареєстрованих суб'єктів господарювання; середньомісячна заробітна плата найманих працівників; кількість вибулого населення; частка надходжень від сплати місцевих податків і зборів у структурі власних доходів місцевого бюджету. На основі проведеного дослідження виокремлено проблеми формування дохідної частини та сформульовано основні шляхи зміцнення місцевого бюджету Бершадського району.

Ключові слова: доходи місцевого бюджету, місцеві органи влади, міжбюджетні трансферти, податкові надходження, місцевий бюджет, місцеві податки та збори.

Рис. 8, Табл. 2, Літ. 10.

Матвийчук В. И., Грабчак Е. Н.

\section{ДОХОДЫ МЕСТНЫХ БЮДЖЕТОВ: ПРОБЛЕМЫ ФОРМИРОВАНИЯ И ОСОБЕННОСТИ ИСПОЛЬЗОВАНИЯ}

Охарактеризовано современные тенденции формирования и использования финансовых ресурсов местного бюджета. Исследовано динамику объема доходов местного бюджета Бершадского района Винницкой области и их составных элементов в 2013-2017 годах. Проанализирована структура доходов местного бюджета. Установлено, что при увеличении размера доходов их структура сохраняется практически без изменений в течение последних пяти лет и характеризуется сохранением значительного удельного веса межбюджетных трансфертов. Достаточно полно изучены изменения в объемах и структуре каждого составного элемента доходной части местного бюджета. Рассмотрено структуру использования средств местного бюджета. Разработано экономико-математическую модель формирования доходной части местного бюджета Бершадского района с учетом влияния следующих факторов: количество зарегистрированных субъектов хозяйствования; среднемесячная заработная плата наемных рабочих; количество выбывшего населения; доля поступлений от уплаты местных налогов и сборов в структуре собственных доходов местного бюджета. По результатам проведенного исследования определены проблемы 
формирования доходов и сформулированы основные направления укрепления финансовой базы местного бюджета Бершадского района.

Ключевые слова: доходная часть местного бюджета, местные органы власти, межбюджетные трансферты, налоговые поступления, местный бюджет, местные налоги и сборы.

\section{Matviychuk V., Hrabchak K.}

\section{LOCAL BUDGET INCOME: PROBLEMS OF FORMATION AND PECULIARITIES OF USING}

The current trends in the formation and use of financial resources of the local budget are described. The dynamics of local budget revenues in the Bershad district of Vinnytsia oblast and their components for 2013-2017 years are explored. The structure of local budget revenues of Bershad district is analyzed. It was revealed that with the growth of income, their structure remains practically unchanged over the last five years and is characterized by the preservation of a significant share of intergovernmental transfers. The changes in the volume and structure of each component of the revenue part of the local budget are studied in detail. The structure of the use of local budget funds is considered. The economic-mathematical model of formation of the revenue part of the local budget of Bershad region is developed, taking into account the following factors: the number of registered economic entities; average monthly salary of employees; number of abandoned population; the share of revenues from the payment of local taxes and fees in the structure of own revenues of the local budget. On the basis of the research, the problems of the formation of the income part are identified and the main ways of strengthening the local budget of Bershad region are formulated.

Key words: local budget revenues, local authorities, intergovernmental transfers, tax revenues, local budget, local taxes and fees.

Постановка проблеми. Місцеві бюджети $є$ вагомим чинником соціальноекономічного розвитку та фінансової стабільності регіонів, інструментом реалізації державної регіональної політики, джерелом фінансових ресурсів для утримання та розвитку місцевого господарства, забезпечення конституційних гарантій та соціальних потреб населення.

Питома вага власних доходів в загальній структурі місцевих бюджетів України протягом останніх шести років не зазнала суттєвих змін і становить в середньому $45 \%$. Це свідчить про високий рівень фінансової залежності місцевих органів влади від державного бюджету, що значно обмежує можливості їх впливу на соціальноекономічний розвиток регіонів. Тому визначення складу впливових факторів та вивчення особливостей їх дії в процесі формування доходів місцевих бюджетів $\epsilon$ надзвичайно важливим завданням, вирішення якого потребує як теоретичного викладання, так і розробки практичних заходів щодо збільшення кількості стабільних джерел дохідної частини місцевих бюджетів. Це сприятиме підвищенню рівня фінансової незалежності місцевих органів влади та якісному виконанню покладених на них завдань і функцій.

Аналіз останніх досліджень і публікацій. Питанням, які пов'язані 3 формуванням дохідної частини місцевих бюджетів, присвячені праці багатьох вітчизняних науковців, таких як I. Луніна [1], О. Кириленко [1; 2; 3], Т. Бондарук [4], П. Бечко [5], О. Ролінський [5], С. Юрій [6], В. Федосов [6] та інші. Але не зважаючи на значну кількість наукових публікацій у цій сфері, виникає необхідність у пошуку нових 
підходів щодо збільшення обсягу надходжень під час формування дохідної частини місцевих бюджетів.

Метою дослідження є розробка рекомендацій щодо удосконалення процесу формування дохідної частини місцевого бюджету завдяки конкретизації проблем за допомогою економіко-математичного моделювання та визначенню шляхів збільшення доходів місцевого бюджету на прикладі Бершадського району Вінницької області.

Виклад основного матеріалу. Відповідно до Свропейської хартії про місцеве самоврядування [7] головною ознакою фінансової незалежності місцевих органів влади $\epsilon$ наявність у їх розпорядженні обсягу фінансових ресурсів, який є необхідний для виконання як власних, так і делегованих повноважень. Місцем концентрації фінансових ресурсів місцевих органів влади, а отже, фінансовою основою їх діяльності, $є$ саме місцевий бюджет. Наявність місцевих бюджетів підтверджує економічну самостійність місцевих органів влади, дозволяє активізувати господарську діяльність, розвивати інфраструктуру на підвідомчій території, розширювати економічний потенціал регіону, виявляти та використовувати резерви фінансових ресурсів. В свою чергу, це дає можливість місцевим органам влади в більш повному обсязі задовольняти потреби та інтереси територіальних громад і сприяє соціально-економічному розвитку територій.

Відповідно до ст. 9 Бюджетного кодексу України [9] доходи місцевих бюджетів класифікуються за такими групами: податкові надходження, неподаткові надходження, доходи від операцій з капіталом, трансферти. На основі статистичних даних [8] досліджено склад та структуру доходів місцевого бюджету Бершадського району Вінницької області.

В загальній структурі доходів Бершадського району найбільша частка припадає на міжбюджетні трансферти, обсяг яких на кінець 2017 року становив 378,1 млн. грн., що на 202,2 млн. грн. більше, ніж у 2013 році, та на 77,8 млн. грн. більше, ніж у 2016 році (рис. 1). У 2017 році спостерігається незначне зменшення частки міжбюджетних трансфертів в структурі доходів бюджету на 2\% порівняно з 2013 роком (рис.2).

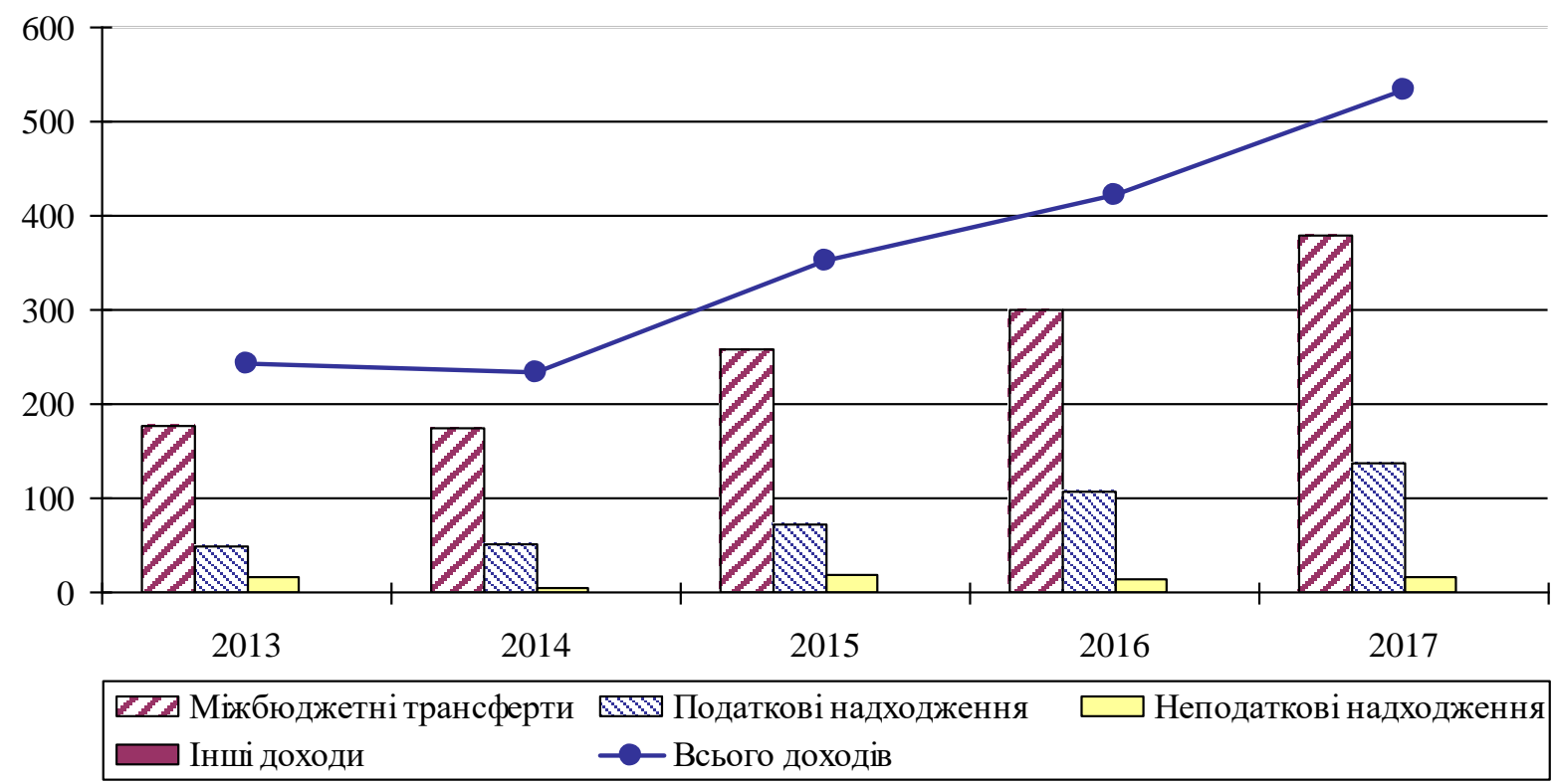

Рисунок 1 - Динаміка доходів місцевого бюджету Бершадського району та їх складових в 2013-2017 роках, млн. грн. 
Друге місце в загальній структурі доходів місцевого бюджету Бершадщини займають податкові надходження, обсяг яких на кінець 2017 року становив 136,7 млн. грн., що на 29,6 млн. грн. більше, ніж у 2016 році. Частка податкових надходжень у загальній структурі доходів бюджету збільшилася з 19,9\% у 2013 році до 25,7\% у 2017 році (рис. 2). Дана ситуація свідчить про наявність тенденції до збільшення частки податкових надходжень у загальній структурі доходів місцевого бюджету.

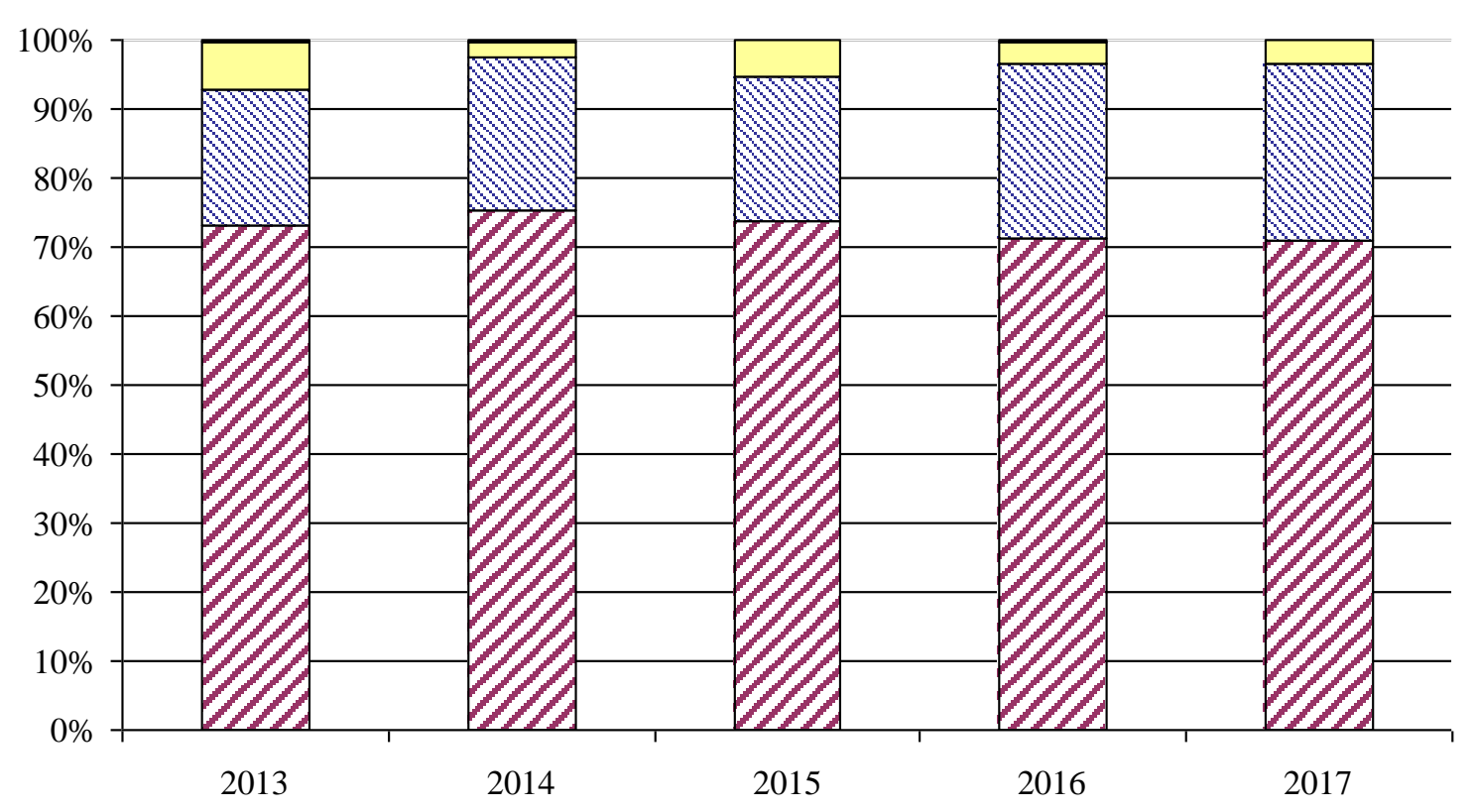

$\boldsymbol{\nabla}$ Міжбюджетні трансферти $₫$ Податкові надходження $\square$ Неподаткові надходження $\square$ Інші доходи

Рисунок 2 - Зміни в структурі доходів місцевого бюджету Бершадського району в 20132017 роках, \%

Найбільшу питому вагу в структурі податкових надходжень місцевого бюджету Бершадщини займає податок на доходи фізичних осіб, обсяг якого протягом аналізованого періоду збільшувався та на кінець 2017 року склав 71,7 млн. грн. Частка даного податку в загальній структурі податкових надходжень протягом 2013-2017 років коливалася в межах від 45,8\% до 67,8\% та на кінець 2017 року склала 52,5\% (рис. 3).

Частка надходжень від сплати місцевих податків і зборів у загальній структурі податкових надходжень Бершадського району протягом 2013-2017 років збільшилася майже в 4 рази, тобто на 28,5\% (див. рис. 3). Таке збільшення пов'язане із впровадженням у 2015 році нового податку - податку на майно, який об'єднав у собі такі податки: податок на нерухоме майно, відмінне від земельної ділянки, плата за землю та транспортний податок.

Частка надходжень від сплати місцевих податків і зборів в загальній структурі доходів місцевого бюджету Бершадщини протягом 2013-2017 років збільшилася з 2,1\% до 10\% (рис. 4). Найбільшу питому вагу у складі надходжень від сплати місцевих податків і зборів займає єдиний податок, обсяг якого з кожним роком зростає і на кінець 2017 року склав 31 млн. грн., що на 26,3 млн. грн. більше, ніж у 2013 році та на 5,8 млн. грн. більше, ніж у 2016 році. Частка єдиного податку в структурі надходжень від сплати місцевих податків і зборів місцевого бюджету Бершадського району на 
кінець 2017 становила 58,3\%, що на 6,1\% більше, ніж у 2015 році та на 4,5\% більше, ніж у 2016 році (рис. 5).

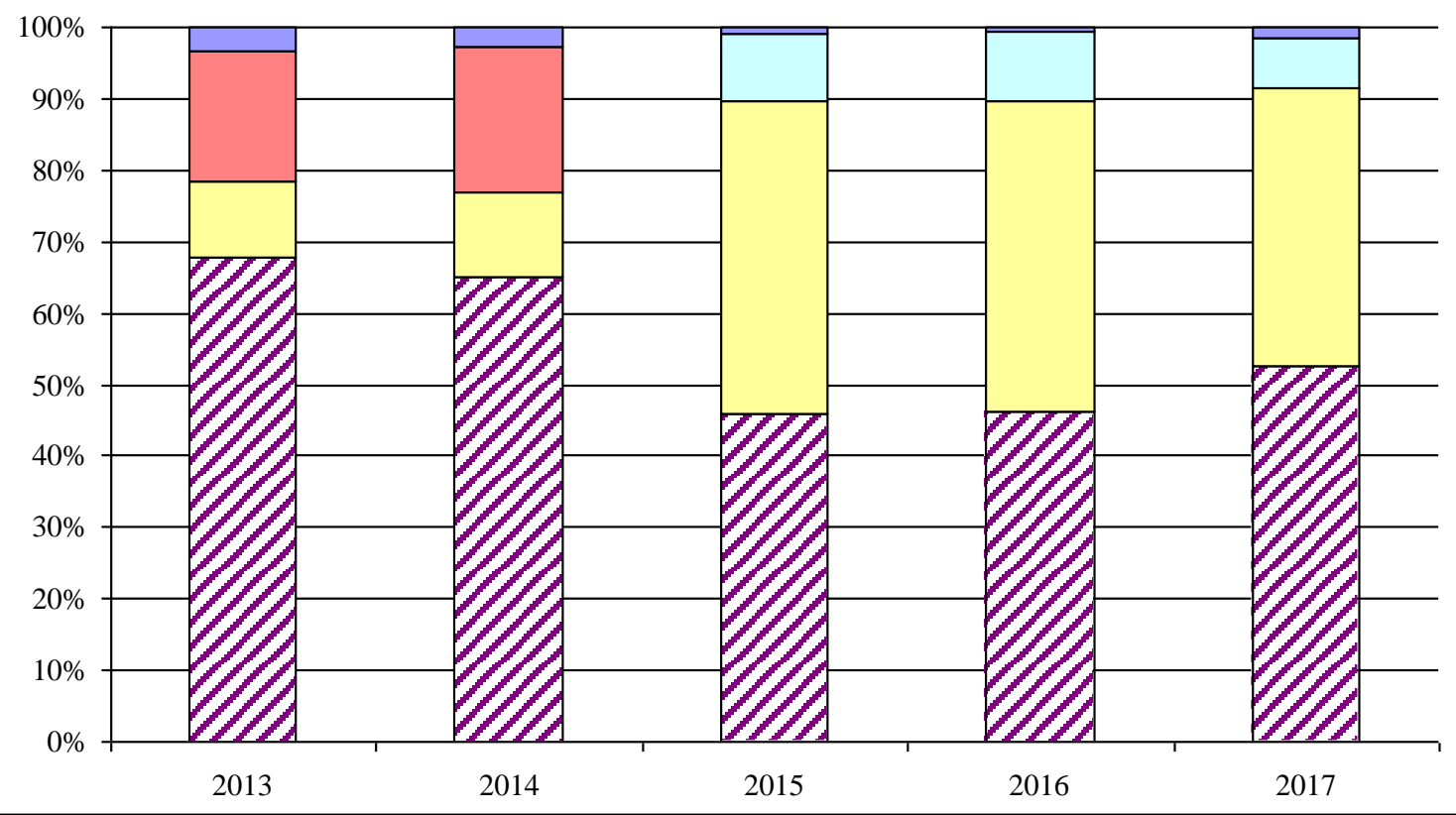

$\nabla$ ПДФО $\square$ Місцеві податки та збори $\square$ Плата за землю $\square$ Акцизний податок $\square$ Інші податки та збори

Рисунок 3 - Динаміка структури податкових надходжень місцевого бюджету Бершадського району в 2013-2017 роках, \%
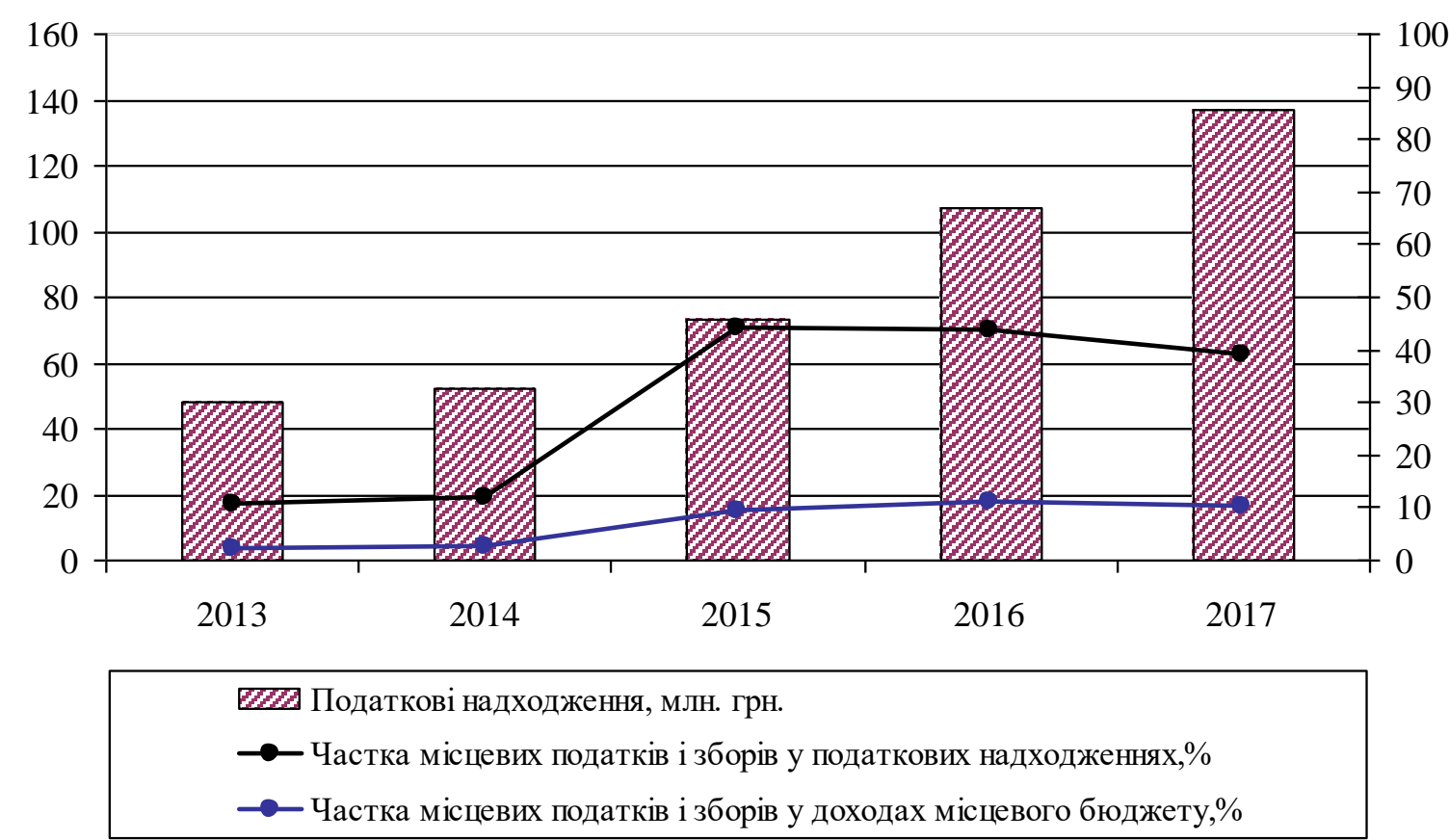

Рисунок 4 - Динаміка обсягу податкових надходжень до місцевого бюджету Бершадського району в 2013-2017 роках 
Обсяг податку на майно у складі надходжень від сплати місцевих податків і зборів на кінець 2017 року становив 22,2 млн. грн., що на 6,8 млн. грн. більше, ніж у 2015 році. Але не зважаючи на збільшення обсягів надходжень від сплати даного податку, його частка у структурі надходжень від сплати місцевих податків і зборів на кінець 2017 року становила 41,7\%, що на 6,1\% менше, ніж у 2015 році (див. рис. 5).

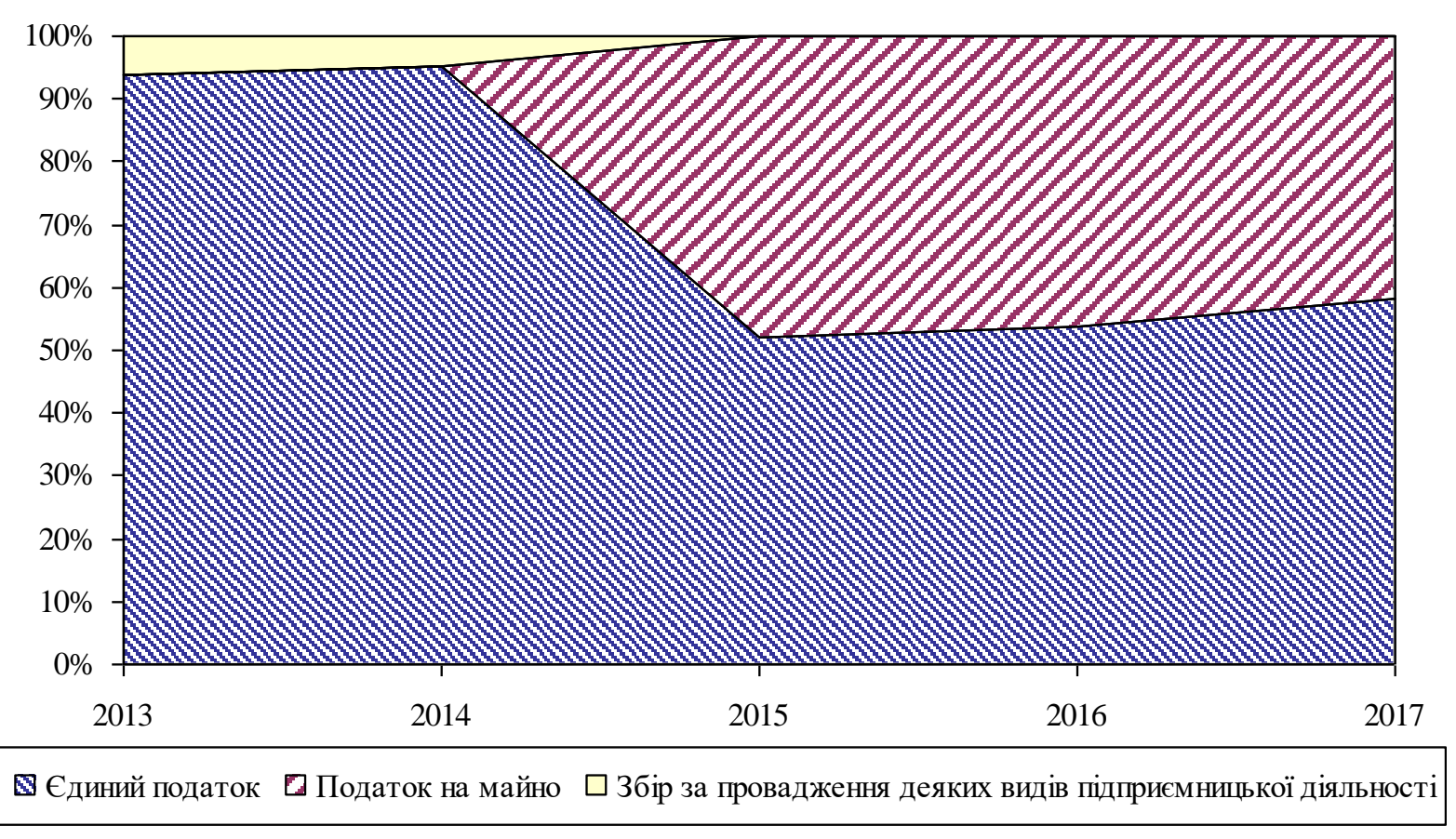

Рисунок 5- Динаміка структури надходжень від сплати місцевих податків і зборів місцевого бюджету Бершадського району в 2013-2017 роках, \%

Неподаткові надходження займають в середньому 4,2\% у складі доходів місцевого бюджету Бершадського району. Їхній обсяг на кінець 2017 року склав 17,2 млн. грн. Для неподаткових надходжень характерним $є$ їхнє формування за рахунок власних надходжень бюджетних установ, частка яких у загальній структурі неподаткових надходжень на кінець 2013 року склала 98,2\%. Власні надходження місцевого бюджету Бершадського району формуються внаслідок отримання плати за послуги, що надаються бюджетними установами згідно з їх основною діяльністю; плати за оренду майна бюджетних установ; завдяки надходженням бюджетних установ від реалізації в установленому порядку майна (крім нерухомого майна) та від додаткової (господарської) діяльності. Значна частина власних надходжень сформована за рахунок благодійних внесків, грантів та коштів, що отримують бюджетні установи від підприємств, організацій, фізичних осіб та від інших бюджетних установ для виконання цільових заходів. У 2017 році можна побачити поступове зменшення цієї частки до $77,3 \%$ (рис. 6). Також слід відмітити тенденцію до збільшення частки доходів від некомерційної господарської діяльності та адміністративних зборів і платежів у загальній структурі неподаткових надходжень з 0,2\% у 2013 році до 18\% у 2017 році. Частка доходів від власності та підприємницької діяльності протягом цих років також збільшилася на 2,5\%.

Проте основним джерелом формування дохідної частини місцевого бюджету Бершадщини залишаються міжбюджетні трансферти. В загальній структурі трансфертів найбільша частка припадає на субвенції, питома вага яких на кінець 2017 року становила 90,6\%, що на 47,6\% більше, ніж у 2013 році (рис. 7). Значні за обсягом 
кошти 3 державного бюджету спрямовуються на виплату допомоги сім ям 3 дітьми, малозабезпеченим сім`ям, інвалідам 3 дитинства, дітям-інвалідам та тимчасової державної допомоги дітям; на надання пільг та житлових субсидій населенню на оплату електроенергії, природного газу, послуг тепло-, водопостачання і водовідведення, квартирної плати; на виплату освітньої та медичної субвенцій.

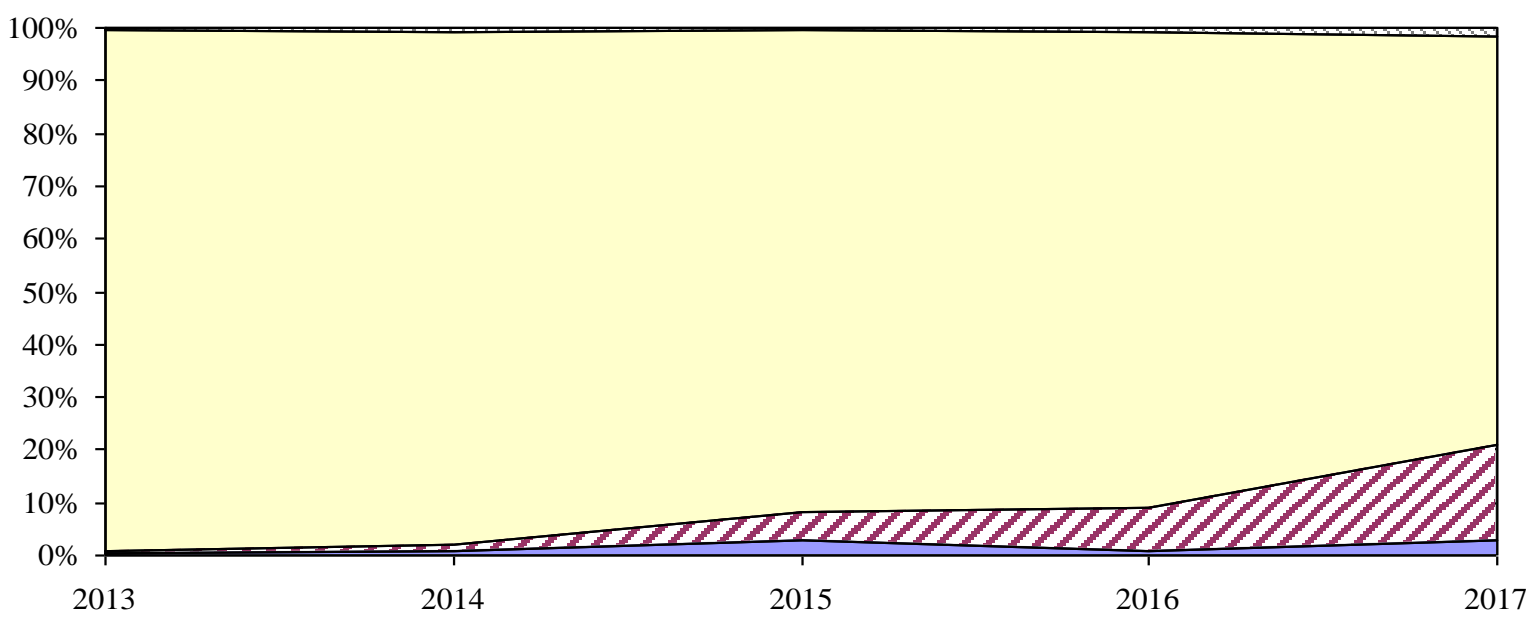

จ Інші неподаткові надходження

$\square$ Власні надходження бюджетних установ

$\checkmark$ Адміністративні збори та платежі, доходи від некомерційної господарської діяльності

$\square$ Доходи від власності та підприємницької діяльності

Рисунок 6 - Динаміка структури неподаткових надходжень місцевого бюджету Бершадського району в 2013-2017 роках, \%

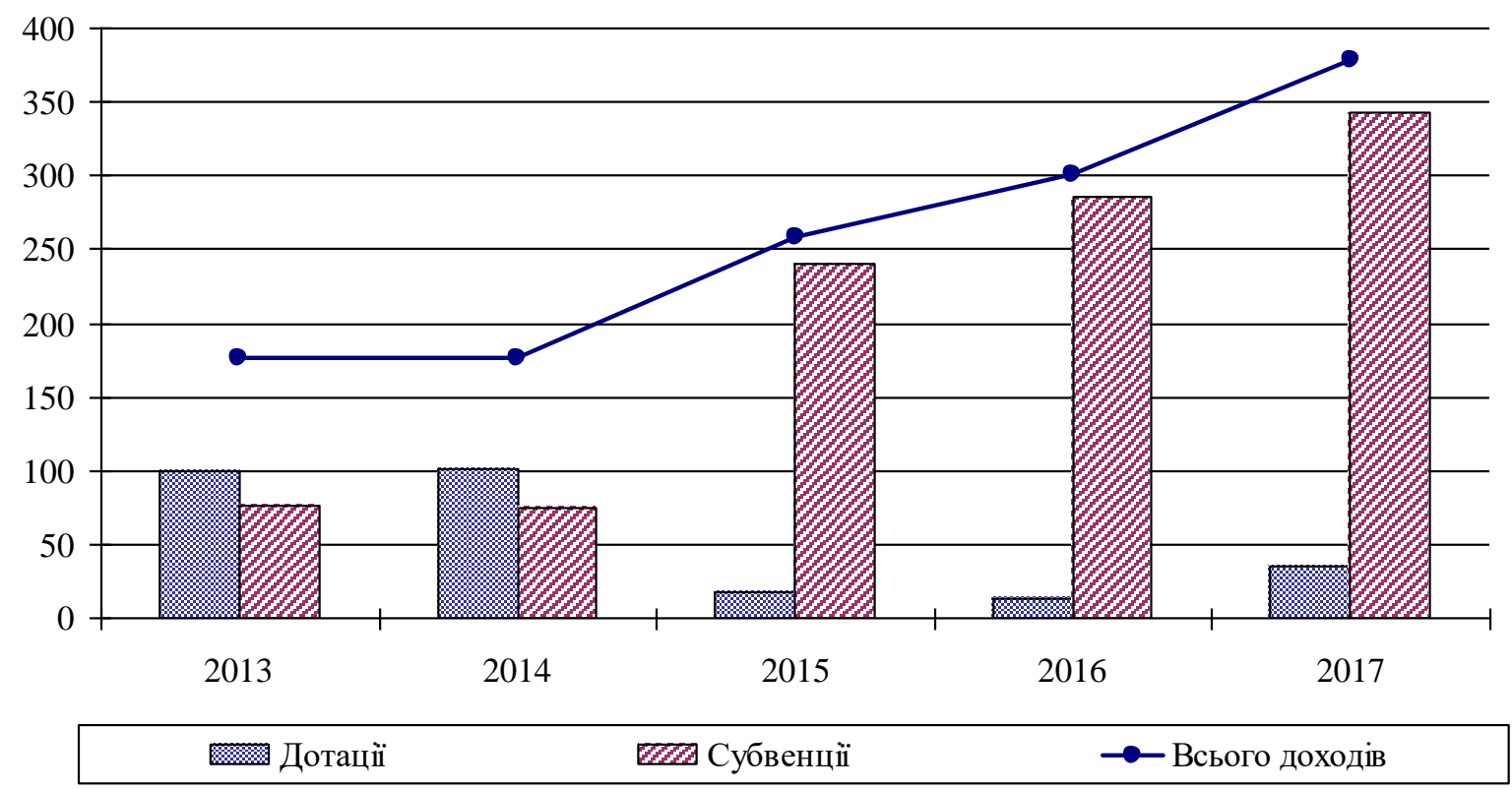

Рисунок 7 - Динаміка міжбюджетних трансфертів місцевого бюджету Бершадського району та їх складових у 2013-2017 роках, млн. грн. 
Потреба у фінансових ресурсах органів місцевого самоврядування визначається обсягом функцій, які вони виконують. Функції місцевих органів влади безпосередньо розкриваються у видатковій частині місцевих бюджетів. Фінансові ресурси місцевих органів влади забезпечують покриття витрат, пов'язаних із вирішенням завдань місцевого характеру, управлінням і розвитком соціальної та економічної сфер певних територій. Основним напрямком використання коштів місцевих бюджетів $\epsilon$ забезпечення завдань соціальної спрямованості.

Використання місцевих фінансових ресурсів відбувається в результаті виконання видаткової частини місцевих бюджетів.

Абсолютні обсяги фінансових ресурсів місцевих органів влади Бершадського району, спрямованих на виконання власних і делегованих повноважень, в період 32013 по 2017 рік зросли практично в 2 рази. Слід зазначити, що збільшення видаткової частини місцевого бюджету, у першу чергу, викликано підвищенням рівня мінімальної заробітної плати, підвищенням тарифів на комунальні послуги, зростанням цін на енергоносії, продукти харчування, медикаменти тощо. Необхідно підкреслити, що зростання загального обсягу видатків місцевого бюджету Бершадського району викликано посиленням інфляційних процесів у країні, а також незадовільним станом інфраструктурних об'єктів, що перебувають у комунальній власності.

У структурі видатків місцевого бюджету Бершадського району (рис. 8) значну частину (в середньому 75,4\%) становлять видатки на охорону здоров'я, освіту, соціальний захист та соціальне забезпечення населення, що фінансуються за рахунок субвенцій, тобто фактично визначаються рішеннями центральних органів влади.

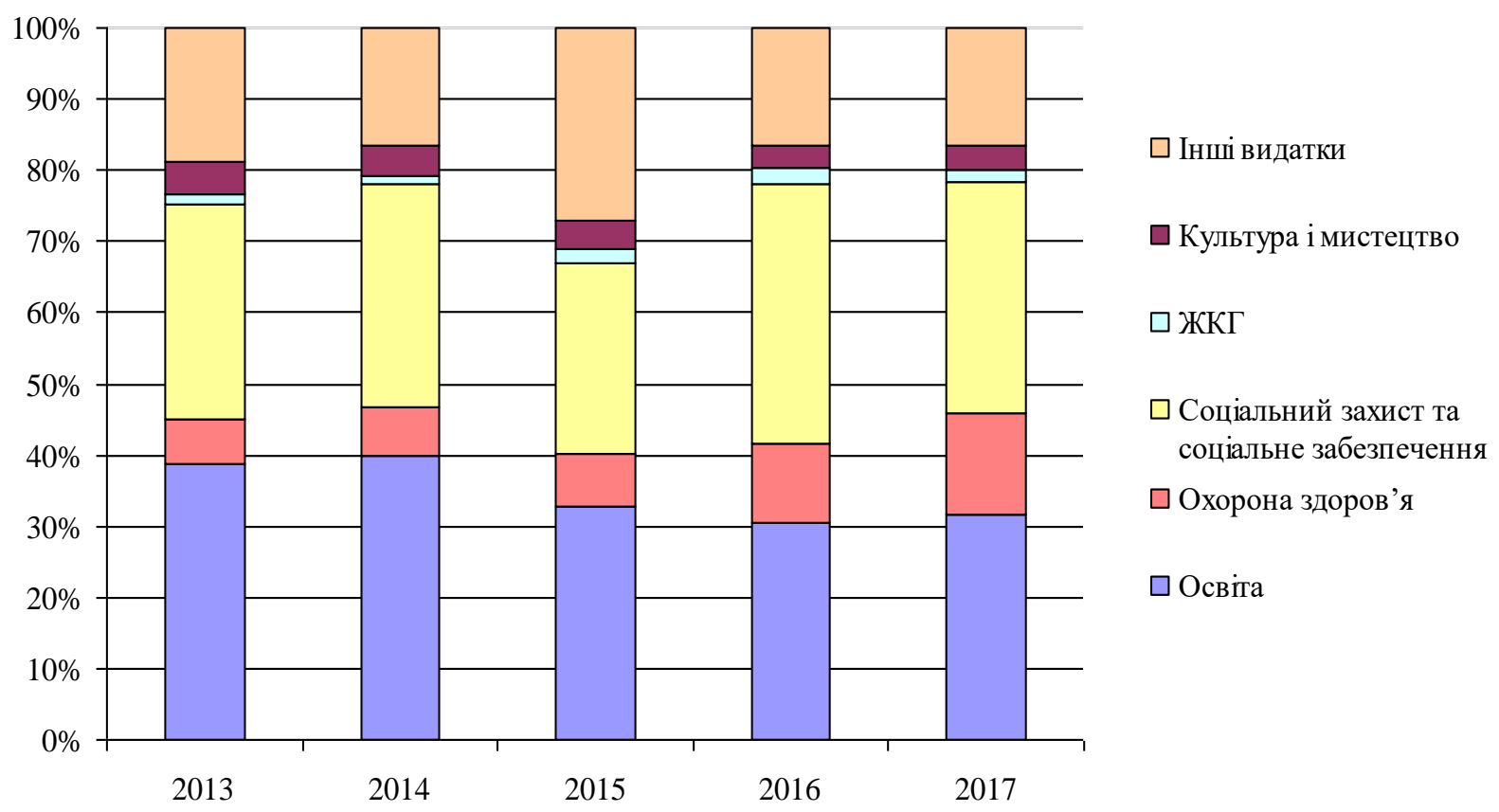

Рисунок 8 - Динаміка структури видатків місцевого бюджету Бершадського району в 2013-2017 роках, \%

У 2017 році на галузі соціальної сфери припадало 85,3\% загального обсягу видатків, що на 1,4\% більше, ніж у 2013 році (див. рис. 8). Порівняно з 2013 роком відбулося зростання частки наступних видатків місцевого бюджету Бершадського району: у галузі соціального захисту населення - на 2,4\%, галузі охорони здоров'я - на 
7,9\%. Частка інших видатків у галузі соціальної сфери зменшилася, не дивлячись на збільшення їхнього обсягу: у галузі освіти - на 7,1\%, галузі культури - на 1,4\%. Висока питома вага видатків у соціальну сферу $є$ позитивною для суспільства, адже як в поточному періоді, так і на майбутнє це дозволяє вирішити низку питань соціальноекономічного розвитку району.

Вивчення існуючих тенденцій щодо формування та використання коштів місцевого бюджету Бершадського району дозволяє визначити наступні показники, які є впливовими чинниками на дохідну частину:

- кількість суб'єктів господарювання, які є основними платниками податків;

- розмір середньомісячної заробітної плати найманих працівників, який $\epsilon$ основою для визначення обсягу податкових платежів;

- кількість вибулого населення, яка характеризує існуючі тенденції міграції в регіоні;

- частка надходжень від сплати місцевих податків і зборів у структурі власних доходів місцевого бюджету, що свідчить про ступінь активності місцевої влади стосовно диференційованого підходу до встановлення податкових норм.

На основі статистичних даних [8; 10] розроблено математичну модель впливу винайдених факторів на процес формування дохідної частини місцевого бюджету Бершадського району. Інформаційну базу дослідження формують дані по Бершадському району, часовий інтервал яких становить 13 років.

В цілях даного дослідження, а також враховуючи результати аналізу проведених досліджень 3 даної проблематики, залежною змінною обрано доходи місцевого бюджету Бершадського району (тис. грн.) - $Y_{t}$, де $t-$ відповідний рік. Було обрано набір змінних величин, які впливають на формування дохідної частини місцевого бюджету (табл. 1).

Таблиця 1 - Змінні величини економетричної моделі та їх інтерпретація

\begin{tabular}{|c|c|}
\hline Змінна & Зміст \\
\hline$Y_{t}$ & Доходи місцевого бюджету Бершадського району, тис. грн. \\
\hline$x_{1}$ & Кількість зареєстрованих суб’єктів господарювання, од. \\
\hline$x_{2}$ & Середньомісячна заробітна плата найманих працівників, грн. \\
\hline$x_{3}$ & Кількість вибулого населення з Бершадського району, ос. \\
\hline$x_{4}$ & $\begin{array}{c}\text { Частка надходжень від сплати місцевих податків і зборів у структурі } \\
\text { власних доходів місцевого бюджету Бершадського району, \% }\end{array}$ \\
\hline
\end{tabular}

Моделювання проводилось на основі сформованих даних 3 використанням програмного продукту EViews, вибір якого для побудови адекватної моделі обумовлений можливістю використання максимальної кількості описової статистики, зручністю доступу до статистичних таблиць, достовірністю розрахунків, обробкою статистичних даних різних типів, побудовою графіків тощо. Оцінка параметрів моделі проводилась за допомогою методу найменших квадратів.

Для проведення емпіричного аналізу було обрано таку модель множинної лінійної регресії:

$$
Y_{t}=a_{1}+a_{2} x_{1}+a_{3} x_{2}+a_{4} x_{3}+a_{5} x_{4}
$$

де $Y_{t}$ - значення досліджуваного показника (залежна змінна) в момент часу $t$;

$a_{1}, a_{2}, a_{3}, a_{4}, a_{5}$ - параметри моделі, які потрібно оцінити;

$x_{1}, x_{2}, x_{3}, x_{4}-$ незалежні змінні. 
Результати отриманих розрахунків за доходами місцевого бюджету Бершадського району в проміжку 2005-2017 років, оцінених методом найменших квадратів, наведено в таблиці 2.

Таблиця 2. - Результати оцінки множинної регресії

\begin{tabular}{|c|c|c|c|c|}
\hline & Коефіцієнт & Ст. похибка & t-статистика & Р-значення \\
\hline Const & $-203491,3$ & 93697,60 & $-2,171788$ & 0,0579 \\
\hline$x_{1}$ & 321,3540 & 124,0285 & 2,590968 & 0,0292 \\
\hline$x_{2}$ & 76,98966 & 5,699396 & 13,50839 & 0,0000 \\
\hline$x_{3}$ & $-113,8872$ & 29,49997 & $-3,860588$ & 0,0038 \\
\hline$x_{4}$ & 2199,321 & 524,2454 & 4,195213 & 0,0023 \\
\hline $\begin{array}{r}\text { Скориг } \\
\text { Cn } \\
\text { Сума к } \\
\text { Логіг } \\
F- \\
3\end{array}$ & $\begin{array}{l}\text { вадрат } \\
\text { ний R-квадрат } \\
\text { ом. моделі } \\
\text { рата залишку } \\
\text { вірогідність } \\
\text { ıтистика } \\
\text { имість } F\end{array}$ & $\begin{array}{l}0,989155 \\
0,985540 \\
15725,22 \\
2,23 \mathrm{E}+09 \\
-141,6753 \\
304,8102 \\
0,000000 \\
\end{array}$ & $\begin{array}{c}\text { Середня зал. змін } \\
\text { Ст. відх. зал. змін } \\
\text { Критерій Акаіке } \\
\text { Критерій Швариза } \\
\text { Критерій Хеннана-Куінна } \\
\text { Стат. Дарбіна-Уотсона }\end{array}$ & $\begin{array}{l}223626,3 \\
137945,7 \\
22,41158 \\
22,58541 \\
22,37585 \\
1,698003\end{array}$ \\
\hline
\end{tabular}

Дана модель статистично значима на високому рівні і може бути представлена в наступному вигляді:

$$
Y_{t}=-203491,3+321,3540 x_{1}+76,98966 x_{2}-113,8872 x_{3}+2199,321 x_{4}
$$

Отримані стандартні характеристики якості моделі свідчать, що:

- незалежні змінні достатньо добре пояснюють залежну змінну $(\mathrm{R} 2=0,99)$;

- помітний функціональний зв'язок, тобто можна стверджувати про суттєвий вплив факторів на дохідну частину місцевого бюджету Бершадського району;

- статистична значимість змінних $x_{1}, x_{2}, x_{3}, x_{4} \epsilon$ високою, отже, модель $\epsilon$ якісно прийнятною. Тобто можна вірити отриманому результату.

3 наведених результатів моделювання можна зробити висновок, що за умови незмінності дії інших факторів, збільшення кількості зареєстрованих суб'єктів господарювання на одиницю зумовлює зростання доходів місцевого бюджету на 321 тис. грн.; зростання розміру середньомісячної заробітної плати найманих працівників в регіоні на 1 гривню сприяє збільшенню дохідної частини бюджету на 77 тис. грн.; збільшення кількості вибулого населення з Бершадського району на 1 особу сприяє зменшенню доходів бюджету на 113 тис. грн.; підвищення частки надходжень від сплати місцевих податків і зборів у структурі власних доходів місцевого бюджету на $1 \%$ зумовлює зростання дохідної частини місцевого бюджету Бершадського району на 2199 тис. грн. Раціональне управління з боку місцевої влади винайденими чинниками дозволяє здійснити позитивний вплив на загальний обсяг дохідної частини бюджету.

Таким чином, проведене економетричне моделювання доходів місцевого бюджету Бершадського району дає змогу виявити соціально-економічні проблеми формування дохідної частини бюджету та слугує основою для розробки системи ефективних заходів щодо іiї збільшення завдяки формуванню відповідної бюджетної політики регіону. 
В контексті трансформаційних процесів, що відбуваються в державі, можна виділити такі актуальні проблеми формування дохідної частини місцевого бюджету Бершадського району:

- залежність повноти та якості реалізації заходів бюджетної політики регіону від надходжень 3 Державного бюджету, що свідчить про нестабільність джерел формування дохідної частини місцевого бюджету;

- переважання частки міжбюджетних трансфертів у загальній структурі доходів місцевого бюджету, що суттєво зменшує роль інших груп доходів в процесі формування доходів місцевого бюджету;

- збільшення частки субвенцій у структурі міжбюджетних трансфертів протягом останніх років до 90,6\%, що підтверджує обмеженість фінансової самостійності місцевих органів влади та неспроможність значною мірою самостійно забезпечувати та координувати соціально-економічний розвиток територій;

- низька питома вага надходжень від сплати місцевих податків і зборів у структурі доходів бюджету, що свідчить про неможливість місцевих органів влади винайти власні джерела поповнення доходу;

- негативна тенденція зменшення кількості працездатного населення, що призводить до скорочення обсягу відповідних податкових надходжень та платежів до місцевого бюджету;

- спрямування значної частини податкових надходжень місцевого бюджету (податку на доходи фізичних осіб, податку на прибуток підприємств, податку на додану вартість, акцизного податку) до державного бюджету, що виступає причиною низької питомої ваги податкових надходжень в структурі місцевого бюджету;

- відсутність зацікавленості місцевих органів влади у максимальній мобілізації надходжень від сплати як місцевих, так і загальнодержавних податків і зборів.

Висновки. Аналіз формування та використання дохідної частини місцевого бюджету Бершадського району Вінницької області вказує на пряму залежність місцевих органів влади від міжбюджетних трансфертів із державного бюджету. Це свідчить про нестабільність формування доходів місцевого бюджету та неможливість органів місцевого самоврядування самостійно і в повному обсязі забезпечувати соціально-економічний розвиток підвідомчих територій.

Процеси фінансово-бюджетної децентралізації, що нині є ключовим вектором розвитку для бюджетної системи України, відбуваються повільно та не сприяють нарощенню дохідної бази місцевих органів влади. Той факт, що частка офіційних трансфертів у загальній структурі доходів місцевого бюджету Бершадського району протягом останніх п'яти років стабільно була вище 70\%, вказує на те, що місцеві органи влади не відчули суттєвих позитивних зрушень у формуванні своєї дохідної бази.

3 метою збільшення дохідної частини місцевого бюджету Бершадського району місцевим органам влади доцільно вжити таких першочергових заходів:

- стимулювати приплив інвестицій за допомогою системи податкових пільг для суб'єктів господарювання, які мають диференціюватися від часткового до повного звільнення від сплати податків на весь термін реалізації інвестиційних проектів регіонального значення. Це дає можливість забезпечити зростання податкових надходжень на перспективу;

- створювати нові високоефективні виробничі підприємства та робочі місця 3 метою забезпечення зайнятості населення, що, у свою чергу, приведе до зменшення кількості вибулого населення та збільшення податкових надходжень району; 
- спільно з контролюючими органами розробити план заходів, спрямованих на повну мобілізацію надходжень від сплати податків і зборів до місцевого бюджету;

- використовувати диференційований та обгрунтований підхід до встановлення норм місцевих податків та платежів 3 метою забезпечення прозорості економічної діяльності та мобілізації достатнього обсягу коштів до місцевого бюджету.

Обов'язковими елементами системи управління процесом формування доходів місцевого бюджету повинні залишатися контроль за діяльністю юридичних і фізичних осіб-суб'єктів підприємницької діяльності, які порушують податкове законодавство; ефективний контроль за формуванням та використанням дохідної частини бюджету; боротьба 3 тіньовою економікою 3 метою збільшення податкових надходжень до дохідної частини місцевого бюджету.

Перспективами для подальших досліджень у даному напрямі $є$ дослідження процесу формування дохідної частини місцевих бюджетів в зарубіжних країнах та співставлення й врахування практичного досвіду для умов України.

\section{Література:}

1. Диверсифікація доходів місцевих бюджетів : моногр. / [Луніна I. О., Кириленко О. П., Лучка А. В. та ін.] ; за ред. д.е.н. І. О. Луніної ; НАН України; Ін-т екон. та прогнозув. - К., 2010. - 320 с.

2. Кириленко О. П. Теоретичні та практичні аспекти фінансового механізму забезпечення органів місцевого самоврядування в Україні / О. П. Кириленко // Світ фінансів. - 2010. - № 1. - С. 17-27.

3. Кириленко О. П. Дохідна база місцевих бюджетів в умовах реформування бюджетної та податкової системи / О.П.Кириленко // Методологічні проблеми фінансової теорії та практики в умовах проведення системних реформ : матеріали наук. конф. проф.-викл. складу. - Тернопіль : Вектор, 2011. - С. 6-10.

4. Бондарук Т. Г. Доходи місцевих бюджетів в умовах децентралізації / Т. Г. Бондарук // Науковий вісник Національної академії статистики, обліку та аудиту. 2015. - № 1. - С. 51-56.

5. Бечко П. К., Ролінський О. В. Місцеві фінанси: навч. посіб. - К.: Центр учбової л-ри, 2007. - 192 с.

6. Бюджетна система : підруч. / за наук. ред. В. М. Федосова, С. І. Юрія. - К. : Центр учбов. Літератури ; Тернопіль : Екон. Думка, 2012. - 871 с.

7. Європейська хартія про місцеве самоврядування, ратифікована Законом України № 452/97 - ВР від 15.07.97 - [Електронний ресурс] - Режим доступу: http://zakon2.rada.gov.ua/laws/show/994_036

8. Офіційний веб-сайт Бершадської районної державної адміністрації / [Електронний ресурс] - Режим доступу: http://rdabershad.gov.ua/ru/

9. Бюджетний кодекс України від 08.07.2010 p. № 2456-VI [Електронний pecypc] - Режим доступу: http://zakon2.rada.gov.ua/laws/show/2456-17

10. Офіційний веб-сайт Головного управління статистики у Вінницькій області / [Електронний ресурс] - Режим доступу: http://www.vn.ukrstat.gov.ua/ 